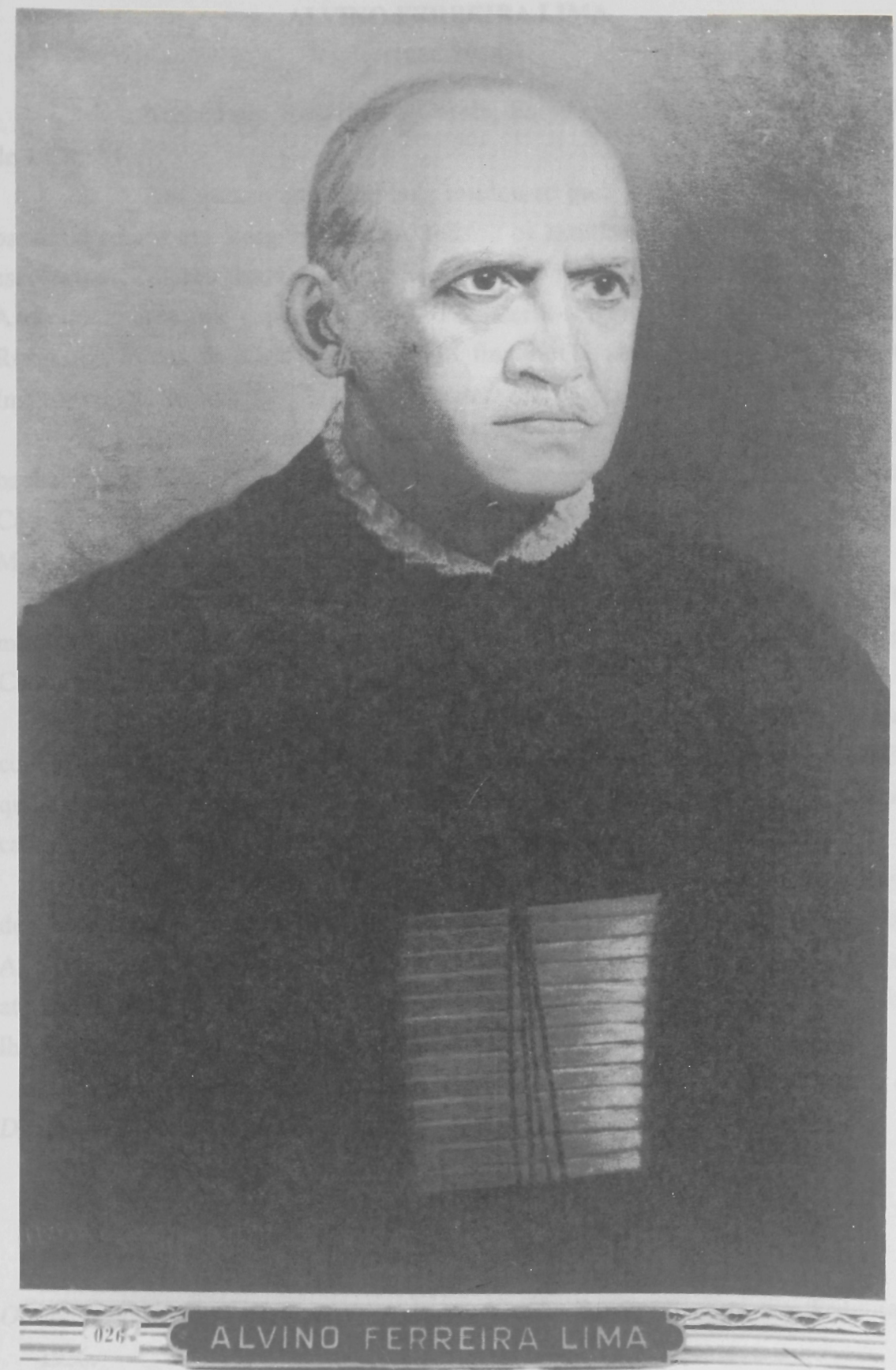





\section{ALVINO FERREIRA LIMA}

(1956-1958)

Nasceu em Rosário do Catete, Estado de Sergipe, a 09 de agosto de 1888.

Aos quatro anos de idade mudou-se para o Estado de São Paulo e passou a residir em Vargem Grande. Iniciou os estudos das primeiras letras em escolas particulares desta cidade, sendo que, em 1899, entrou para o Colégio Azevedo Soares, na capital paulista. Transferiu-se, em 1900, para o Colégio Rosas, de Poços de Caldas, concluindo finalmente seus estudos em 1904 no Instituto de Ciências e Letras desta capital.

Em 1904, ingressou na Faculdade de Direito de São Paulo, bacharelando-se em 1908. Em abril de 1909, começou a exercer a advocacia em Casa Branca, onde ocupou por cerca de dez anos o cargo de lente de Matemática da Escola Normal.

Ingressou na vida política local, tendo sido eleito prefeito municipal, de 1922 a 1923, e posteriormente ocupado o cargo de presidente da Câmara Municipal.

Em 1925, transferiu-se para esta capital fazendo seu primeiro concurso de Direito Civil na Faculdade de Direito de São Paulo no ano de 1936, quando recebeu o título de doutor em Direito e foi nomeado livre-docente da cadeira, da qual veio a tornar-se professor catedrático em 1939.

Por vários anos exerceu a vice-diretoria desta Faculdade, tendo desempenhado também as funções de membro do Conselho TécnicoAdministrativo. Em setembro de 1956, foi nomeado diretor, cargo que exerceu até sua aposentadoria compulsória, em agosto de 1958. Em agosto de 1966, foithe conferido o título de professor emérito.

Colaborou na Revista dos Tribunais, na Revista da Faculdade de Direito e em diversos jornais de São Paulo, além das obras que seguem.

Faleceu a 03 de agosto de 1975.

\section{Obras Publicadas}

O direito de retenção e o possuidor de má-fé. São Paulo : Revista dos Tribunais, 1936. 
Da culpa ao risco. São Paulo : Revista dos Tribunais, 1938.

A reparação civil do dano no anteprojeto do código das obrigações. Revista Forense, Rio de Janeiro, v. 97, p. 13, 1944.

Culpa e risco. São Paulo : Revista dos Tribunais, 1960.

A fraude no direito civil. São Paulo : Saraiva, 1965. 